\title{
The structural glaciology of Kongsvegen, Svalbard, and its role in landform genesis
}

\author{
Neil F. Glasser, ${ }^{1}$ Mighael J. Hambrey, ${ }^{2}$ Kevin R. Crawford, ${ }^{3}$ \\ Matthew R. Bennett, ${ }^{4}$ David Huddart ${ }^{5}$ \\ ${ }^{1}$ School of Biological and Earth Sciences, Liverpool Fohn Moores University, Byrom Street, Liverpool L3 3AF, England \\ ${ }^{2}$ Institute of Geography and Earth Sciences, University of Wales, Aberystwyth, Ceredigion S123 3DB, Wales \\ ${ }^{3}$ Department of Environmental and Biological Studies, Liverpool Hope University College, Hope Park, Liverpool L16 9 JD, England \\ ${ }^{4}$ School of Earth and Environmental Sciences, University of Greenwich, Medway Campus, Chatham Maritime, Kent ME4 4AW, England \\ ${ }^{5}$ School of Education and Community Studies, Liverpool Fohn Moores University, I. M. Marsh Campus, Liverpool L17 6BD, England
}

\begin{abstract}
Mapping of the structural glaciology of Kongsvegen, Svalbard, reveals evidence for four main deformational structures. These are stratification, longitudinal foliation, thrusts and crevasse traces. These structures are considered in terms of their contribution to debris entrainment, transport and subsequent landform development. Stratification is associated with small amounts of supraglacial debris that has been folded with flow-parallel axes; longitudinal foliation in places incorporates basal glacial sediments along folds with flow-parallel axes; and thrusts transport basal debris to the glacier surface. Crevasse traces are not significant in terms of debris entrainment. The entrainment of basal debris along longitudinal foliation is not a universally recognised process. At Kongsvegen this process is attributed to the development of a transposition foliation, in combination with incorporation of debris-rich basal ice or soft basal sediment in the fold complex. Mapping of the landforms in the proglacial area shows that debris incorporated along longitudinal foliation is released as "foliation-parallel ridges" and that transverse ridges mark debris-bearing thrusts. The role of longitudinal foliation in landform development has never been documented in this manner. Although the preservation potential of such ridges may be limited, recognition of foliation-parallel ridges in the Pleistocene landform record has important implications for the interpretation of the dynamics of former ice masses.
\end{abstract}

\section{INTRODUCTION}

Although structural attributes such as folds, faults, crevasse traces and foliation are commonly described in glaciers (Allen and others, 1960; Ragan, 1969; Hambrey, 1975, 1977; Hambrey and Milnes, 1975; Hambrey and Müller, 1978; Hooke and Hudleston, 1978; Hudleston and Hooke, 1980; Casassa, 1992; Lawson and others, 1994), the origin and significance of many of these structures remains unclear. In particular, the role of these structures in debris entrainment and transport and their potential contribution to landform development has rarely been considered. In this paper the structural evolution of the glacier Kongsvegen in Svalbard is examined with respect to the role of ice-deformational processes in landform development. This has important implications because traditional models of landform development have ignored the possibility that these ice deformational processes are capable of producing discrete and recognisable landforms. This paper builds on previous work at Kongsvegen (Bennett and others, 1996a) and has three specific aims:

(a) To outline the structural glaciology of the lower reaches of Kongsvegen, emphasising those structures that developed as a result of the 1948 advance and their role in debris entrainment, transport and deposition. (b) To describe the formation of these structures, on the basis of their morphology, ice-debris facies and structural attributes.

(c) To consider the implications of these results for models of landform genesis in glaciers.

Foliation is a planar or layered structure developed in glaciers, often defined by variations in bubble or dirt content within the ice. This structure generally develops from pre-existing layers, most notably from primary stratification and the traces of former crevasses (Hooke and Hudleston, 1978). Its development is due to the folding and transposition of these pre-existing layers. The degree of compression or shearing determines the tightness of folding and therefore the inclination of foliation. In extreme cases, vertical foliation can develop if there is sufficient compression to cause attenuation of the folds. Although foliation can be arranged in both longitudinal and transverse directions with respect to glacier flow, at Kongsvegen there is evidence only of longitudinal foliation and we therefore limit our discussion to this structure. Longitudinal foliation occurs on both surge-type and non-surge-type glaciers and is characteristically aligned parallel to ice flow. On surgetype glaciers such as Variegated Glacier, Alaska, longitudinal foliation forms in this manner during quiescent phases 
(Lawson and others, 1994). On non-surge-type glaciers such as White Glacier, Canada, it is constantly forming (Hambrey and Müller, 1978). On glaciers subjected to large compressive strain, such as those where ice from a narrow accumulation basin feeds into a narrow tongue, foliation is not limited to the glacier margins but may extend across the entire width of the glacier. Although this structure is now well documented in contemporary glaciers, little is known about its role in the processes of debris entrainment, transport and deposition.

\section{THE KONGSVEGEN GLACIER}

The Svalbard archipelago spans an area from $77^{\circ}$ to $80^{\circ} \mathrm{N}$, is currently $60 \%$ glacierized (Hagen and others, 1993) and is dominated by a maritime-Arctic climate. Many Svalbard glaciers are polythermal in nature, with extensive areas of temperate ice beneath their accumulation areas, and with margins and snouts frozen to bedrock (Hagen and Sxtrang 1991; Björnsson and others, 1996). This study is based on the northwest-flowing Kongsvegen glacier which, together with the glacier Kronebreen, is fed from the highland icefield of Holtedahlfonna. The name Kongsvegen is reserved for the glacier which occupies the southern side of Kongsfjorden, whilst the name Kronebreen is used to describe the glacier which divides around Colletthøgda to form two separate tidewater calving fronts in Kongsfjorden (Fig. 1). In earlier literature, the name Kongsbreen was used to describe the entire glacier complex at the time when the glaciers were confluent in Kongsfjorden, but this term has been abandoned since the recent glacier recession (personal communication from J. O. Hagen, 1997). Kronebreen South now merges with Kongsvegen to form a combined calving front in Kongsfjorden (Fig. 1). Kongsvegen (glacier number 15510 of Hagen and others, 1993) is $27 \mathrm{~km}$ long, with a total area of $189 \mathrm{~km}^{2}$. Kronébreen (glacier number 15511 of Hagen and others, 1993) is $42.7 \mathrm{~km}$ long, with a total area of $690 \mathrm{~km}^{2}$. The Kongsvegen glacier front is almost stationary, with a measured centre-line velocity before convergence of $4.75 \mathrm{~m} \mathrm{a}^{-1}$ (Melvold, 1992). Kronebreen is far more active, with a measured centre-line velocity before convergence of
$737 \mathrm{~m} \mathrm{a}^{-1}$ (Melvold, 1992) The combined ice front of Kronebreen and Kongsvegen is receding at rates of 0 $300 \mathrm{~m} \mathrm{a}^{-1}$, with an average of $200 \mathrm{~m} \mathrm{a}^{-1}$ (Lefauconnier and others, 1994).

The glacier complex is commonly believed to have surged, or at least advanced rapidly, twice in the last 150 years (Liestøl, 1988; Hagen and others, 1993), with rapid advances documented from 1869 and 1948 (Elverhøi and others, 1980). There is, however, no direct or conclusive evidence that either of these rapid advances was a surge. Hagen and others (1993) attribute the rapid advance of the complex in 1869 to Kronebreen, and that of 1948 to Kongsvegen, although the individual role of each glacier in these advances remains unclear. As a result of the 1948 advance, the northwest margin of Kongsvegen is now exposed in a $1 \mathrm{~km}$ longitudinal section on the shore of Kongsfjorden (Fig. 2). This provides a unique opportunity to document ice structures in three dimensions as well as to trace the development of landforms beyond the present ice margin.

\section{METHODS}

The structural evolution of Kongsvegen was determined from analysis of air photographs taken in 1948, 1970 and 1995, and from field mapping of primary stratification, foliation, thrusts and crevasse traces in the summer of 1996. Mapping both on the ice surface and in the vertical longitudinal section allowed the identification of structural attributes in three dimensions. In addition, ice-debris facies were characterised by the field measurement of particle shape. For each clast the following information was recorded: the dimensions of the three orthogonal axes; the clast roundness on a modified Powers (1953) scale; and clast lithology. These data were analyzed using the approach of Benn and Ballantyne (1994) in which the RA index (percentage of angular and very angular clasts) is plotted against the $\mathrm{C} 40$ index (percentage of clasts with $c / a$ axial ratio $<0.4$ ) on a covariant plot. Matrix samples of each of the ice-debris facies were collected for particle-size analysis, involving sieving of the coarse fraction (gravel and sand) and analysis of the fine fraction (silt and clay) using a Sedi-
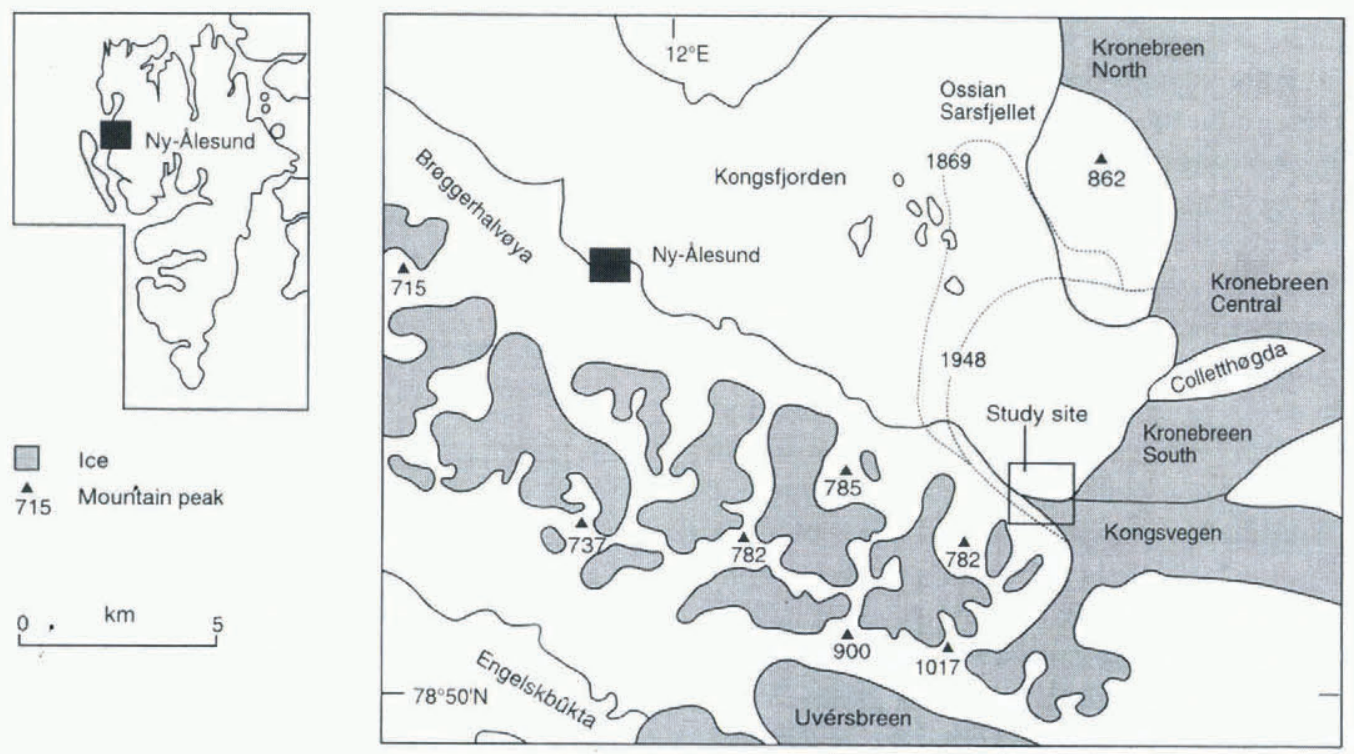

Fig. 1. Location map of the study area, showing Kongsfjorden and the glaciers Kongsvegen and Kronebreen. 


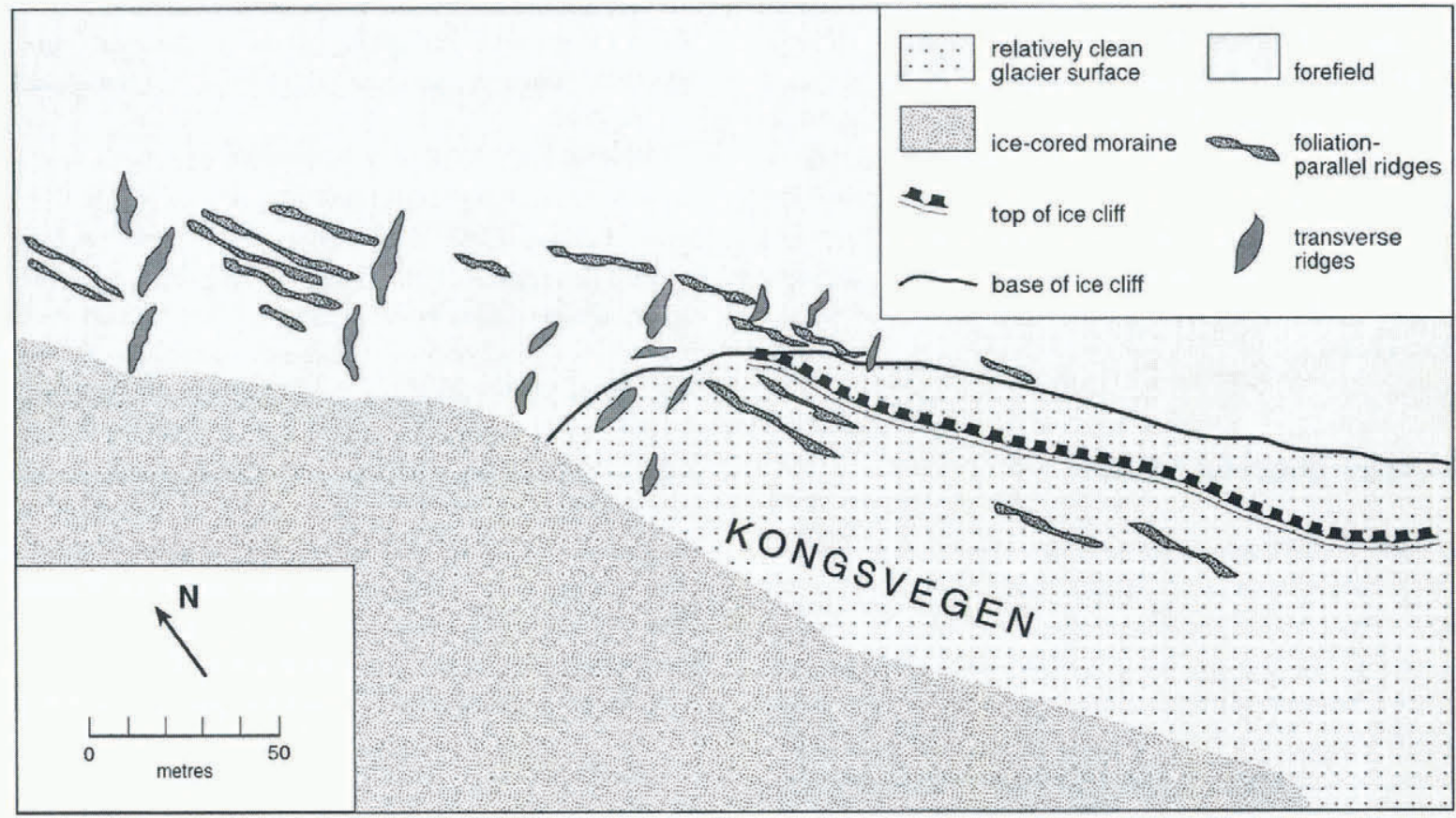

Fig. 2. Map of the terminal area of Kongsvegen, showing the distribution of landforms visible on the ice surface and those directly in front of the receding glacier.

Graph 5000 D Particle Size Analyzer. Mapping of the landforms on the glacier forefield beyond the present margin included those orientated both parallel and transverse to the glacier. A detailed description of their sedimentary facies was also made (including particle shape and particle-size analysis). This enables a direct comparison with sediment samples from the ice-debris facies on the glacier.

\section{DYNAMICS OF THE KONGSVEGEN-KRONE- BREEN COMPLEX INFERRED FROM CREVASSE PATTERNS}

The surface of Kongsvegen is mainly crevasse-free except at the flow-unit boundary with the much faster-flowing Kronebreen and at its calving cliff in Kongsfjorden (Fig. 3). A prominent medial moraine on the glacier surface marks this flow-unit boundary. At this boundary there are short, intersecting, diagonal and transverse crevasses on the glacier surface. The edge of the crevassed area is precisely defined, not by the boundary between the two glaciers, but by the eastern edge of the medial moraine on the surface of Kongsvegen. This is strong evidence that there has been partial reactivation of Kongsvegen ice following its 1948 advance. The terminus of Kongsvegen shows evidence of three distinct flow units, numbered $1-3$ from west to east across the glacier terminus (Fig. 3). Unit 1 is the area from the western ice margin to a prominent medial moraine on the glacier surface. Here the ice appears to be stagnant and shows little evidence of movement. Unit 2 is the area covered by the medial moraine itself, and unit 3 is the area that feeds the main calving front of Kongsvegen. Flow unit 3 is crossed by crevasses parallel to the Kongsvegen calving cliff. These extend into flow unit 2, but are largely obscured by the medial moraine. These crevasses are concave downglacier and their orientation is reflected in the geometry of the calving cliff. Further up-glacier the surface of Kongsvegen is crossed by numerous crevasse traces. By comparison, Kronebreen is extremely heavily crevassed, with open crevasses across its entire width (Fig. 3). The intersection of major transverse and longitudinal crevasses splits the glacier surface into a series of inter-crevasse blocks $10-20 \mathrm{~m}$ in dimension. In places, these inter-crevasse blocks are further subdivided by a set of arcuate (convex down-glacier) crevasses. The heavy crevassing prohibits surface examination of the glacier in the field. The crevasse patterns are reflected by the irregular geometry of the Kronebreen calving cliff.

\section{STRUCTURAL GLACIOLOGY OF KONGSVEGEN FOLLOWING THE 1948 ADVANCE}

Field observations show that the terminal area of Kongsvegen comprises five recognisable types of planar structure (Table 1). These structures are termed $\mathrm{S}_{0}-\mathrm{S}_{4}$ in order of formation according to normal conventions of structural geology. For clarity, the structures in the terminal area of Kongsvegen are described in three subzones, a-c (Fig. 4).

\section{Primary stratification $\left(\mathrm{S}_{0}\right)$}

Primary stratification $\left(\mathrm{S}_{0}\right)$, inherited from snowfall in the accumulation area, is visible only on aerial photographs of Kongsvegen, where it shows up in the middle and upper

Table 1. Summary of the characteristics of the principal structures observed on Kongsvegen

Element Characteristics

$\mathrm{S}_{0} \quad$ Primary stratification derived from snowfall

$\mathrm{S}_{1} \quad$ Longitudinal foliation

$\mathrm{S}_{2} \quad$ Thrusts orientated transverse to glacier flow

$\mathrm{S}_{3} \quad$ Crevasse traces

$\mathrm{S}_{4} \quad$ Basal ice fractures of uncertain origin

$\mathrm{F}_{1} \quad$ Folds associated with foliation development and the incorporation of both basal glacial and supraglacial debris 


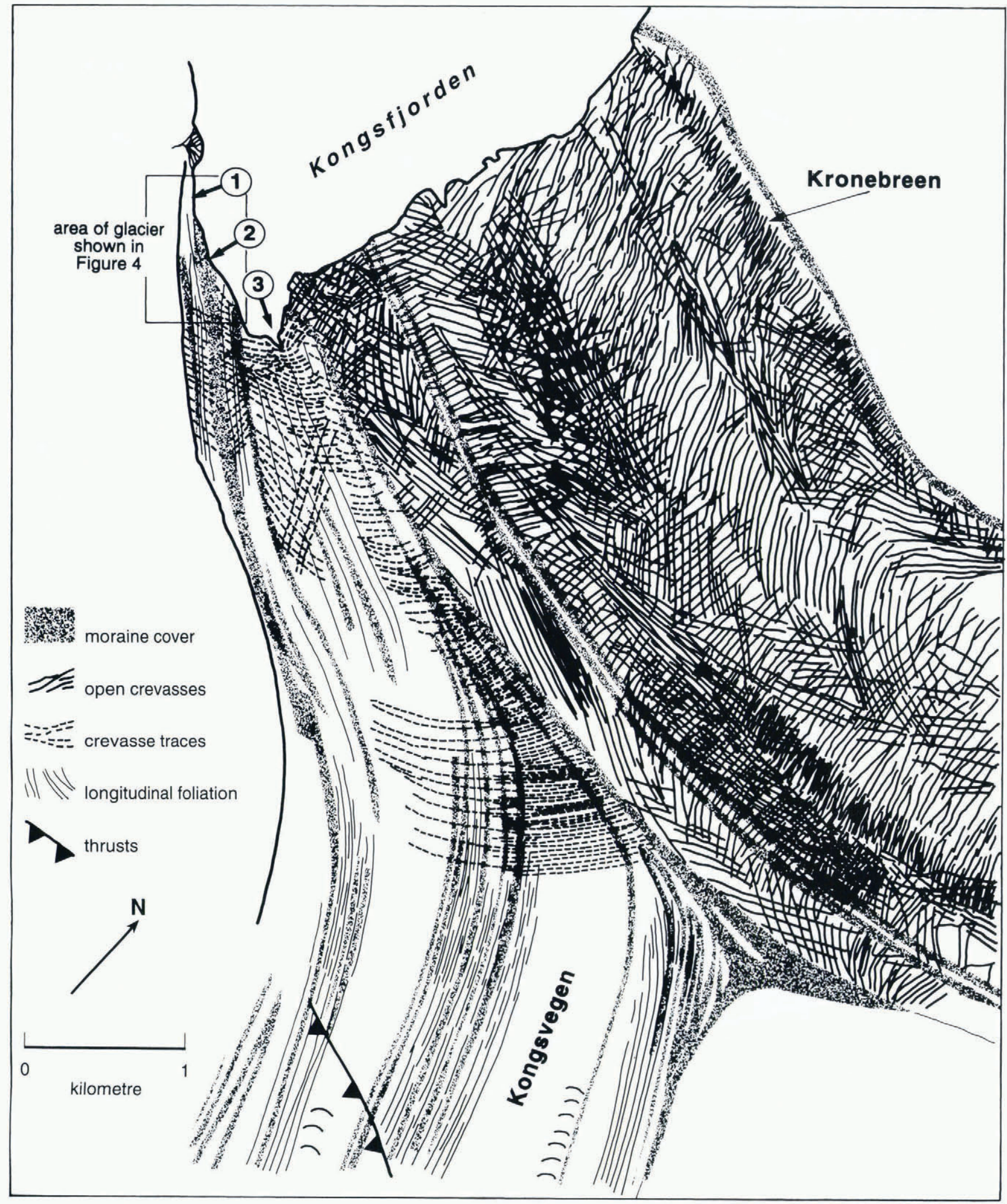

Fig. 3. Crevasse patterns on the glaciers Kongsvegen and Kronebreen south, drawn from the 1995 aerial photograph (uncorrected for edge distortion). Numbers $1-3$ refer to the flow units described in the text.

reaches of the glacier as a diffuse pattern of light and dark ice. Here it forms an irregular pattern on the glacier surface, suggesting gentle dips, although fold hinges are often tight. This stratification is also displayed in cross-section in the Kongsvegen ice cliff, where it is defined by gently dipping layers and thin dirt bands. Primary stratification on Kongsvegen is not obviously associated with large quantities of debris, although longitudinal bands of angular gravel of uniform composition may represent stratification in the form of rockfall material originating in the accumulation area.

Foliation $\left(\mathrm{S}_{1}\right)$ and associated folding $\left(\mathrm{F}_{1}\right)$

Longitudinal foliation $\left(\mathrm{S}_{1}\right)$, as on other glaciers, is visible on the glacier surface as intercalated layers of coarse-bubbly and coarse-clear ice (Allen and others, 1960). No fine ice was observed on the surface of Kongsvegen, a type of ice 
Poles to longitudinal foliation

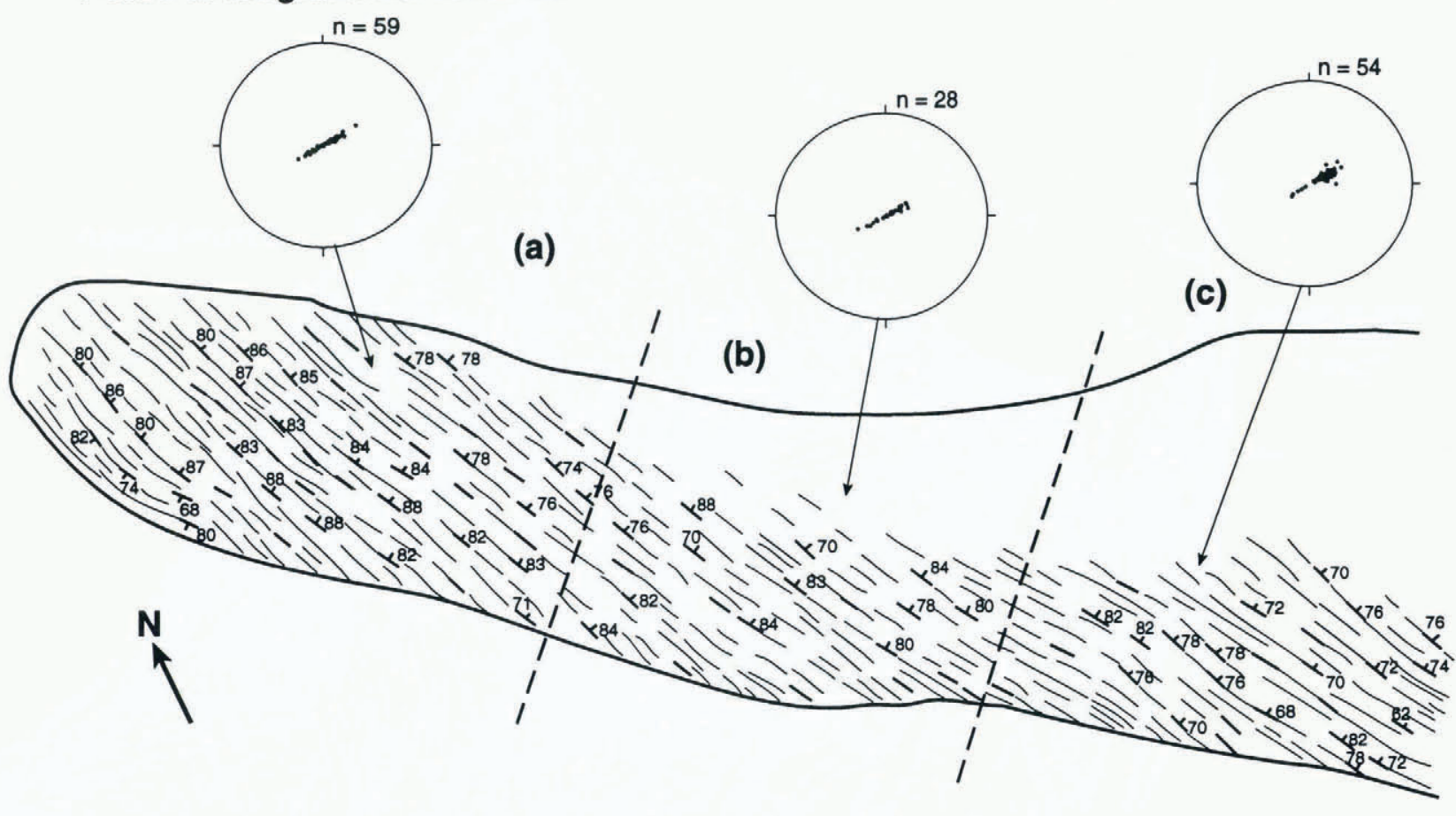

\section{Poles to thrusts}
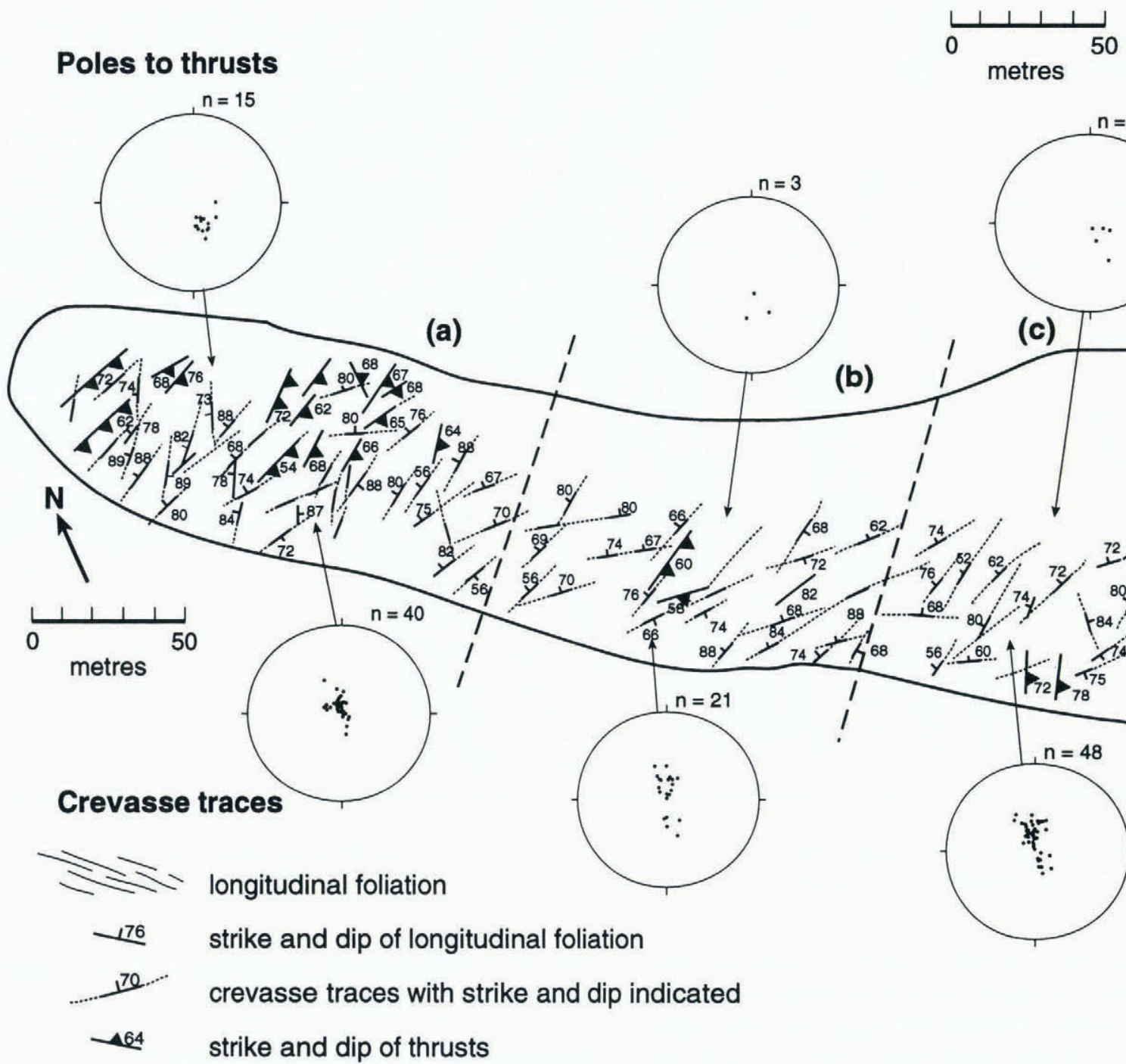

longitudinal foliation

(a)

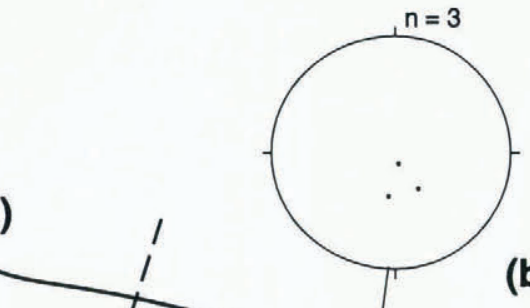

(b)

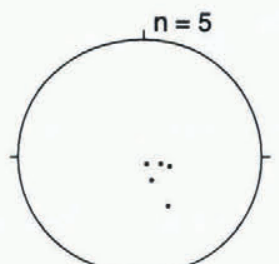

(c)

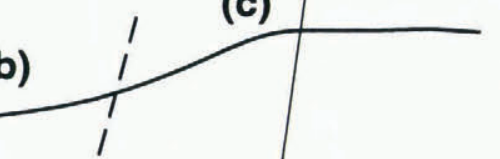


normally associated with active shearing. The foliation has a consistent strike $\left(060-240^{\circ}\right)$, and across the whole glacier surface is orientated sub-parallel to glacier flow (Fig. 4). The foliation has a low-amplitude sinuosity, typically dipping at steep angles of $70-85^{\circ}$ (Fig. 5). Ridges of debris parallel to the foliation occur at several places on the glacier surface (Fig. 2), especially in the lower areas of the glacier (Fig. 6b). Although these ridges are commonly $1-2 \mathrm{~m}$ wide and $1.5 \mathrm{~m}$ high when ice-cored, the source debris layers in the ice below are rarely greater than $0.1 \mathrm{~m}$ wide. The dispersion of material associated with these features is a result of the melting of their ice core. Clasts in these foliation-parallel ridges are mainly subangular and subrounded. Some ridges are composed of a sandy diamicton, which is characterised by subangular and subrounded material, occasionally containing striated clasts. Lithologically, these "foliation-parallel ridges" are highly variable.

Associated with this foliation is isoclinal to similar folding $\left(F_{1}\right)$ formed by the process of transposition. The fold structure is best observed where more gently inclined in the southwest marginal cliff, where it clearly involves debrisrich basal ice. In the relatively clean ice zones, isolated tight fold hinges are present. This suggests that the entire ice mass has been tightly folded, with fold axes orientated parallel to ice flow (Fig. 7). In order to raise debris-rich basal ice to the glacier surface, it is necessary to invoke large-scale folding not only of the ice mass but also of subglacial debris.

\section{Thrusts $\left(\mathrm{S}_{2}\right)$}

The surface of the glacier is crossed by a series of fractures inferred to be thrusts (S2), orientated approximately transverse or diagonal to glacier flow (Fig. 4). Although it is only rarely that evidence of displacement survives, their geometry is similar to that in other glaciers where displacement can be demonstrated. These thrusts are not visible at the scale of aerial photography, although they are a common feature of the Kongsvegen glacier. Thrusts can be observed both on the glacier surface and in cross-section in the ice cliff immediately below. On the glacier surface, thrusts range from discrete planar discontinuities to $0.5 \mathrm{~m}$ thick layers of regelation ice. Thrusts crop out on the glacier surface on the lower $300 \mathrm{~m}$ of Kongsvegen in subarea a, but are less common above this level in subareas b and c (Fig. 4). This is a function primarily of enhanced surface lowering due to the greater ablation in the terminal area and the inference that thrusts did not all necessarily reach the glacier surface during the advance. In the ice cliff, it is possible to see the morphology of these thrusts in cross-section. Thrusts rise gently from the base of the glacier, before steepening upwards to crop out on the glacier surface at angles of $50-85^{\circ}$. The majority of thrusts break the glacier surface at angles of $60-75^{\circ}$ (Fig. 5). These thrust angles are greater than those typically found in non-surge-type glaciers but are typical of those recently formed in surge-type Bakaninbreen in Svalbard (Hambrey and Dowdeswell, 1997). A typical Kongsvegen thrust zone thickens towards the glacier surface, tapering towards the base of the glacier. Many thrusts do not penetrate as far as the glacier surface but terminate in the ice cliff as blind thrusts (Fig. 8b).

An important distinction is between those thrusts which are debris-bearing and those which are not. Where thrusts contain significant quantities of debris, this is usually a clast-rich, muddy diamicton. The diamicton contains a range of clast lithologies, predominantly in the subangular to subrounded range. Many of these clasts are striated and faceted, suggesting that they are basally derived. In some cases, thrusts comprise primarily debris, with a minimum of interstitial ice. Where thrusts break the glacier surface, they are marked by transverse ice-cored ridges of debris. Melting of these ridges reduces the debris concentration to a thin film of mud. In some thrusts the debris-rich zone dies out sharply, and subsidiary thrusts can be seen to have developed (Fig. 8b). On the back of thrusts it is common to see reverse fractures dipping down-glacier. This type of thrusting is a common process in surge-type glaciers (Raymond, 1987) and has been described from surge-type glaciers in Alaska (Lawson and others, 1994) and in Svalbard (Hambrey and others, 1996; Hambrey and Dowdeswell, 1997). In addition, Hisdal (1976) reported the existence of a large fault higher on Kongsvegen near the pass that separates the glacier from Uversbreen. This fault is visible on aerial photographs of Kongsvegen (Fig. 3). Meltwater from the drainage of a large subglacial lake is reported to have surfaced along this fault in May 1975 (Liestøl, 1977). This is further evidence that thrusts may provide a more or less continuous link between the surface and base of the glacier.

\section{Crevasse traces $\left(\mathrm{S}_{3}\right)$}

Crevasse traces $\left(\mathrm{S}_{3}\right)$, extending back from the snout into the upper accumulation basin, are visible on the surface of Kongsvegen. Thrusts are offset by some crevasse traces, demonstrating that the formation of the thrusts predates the formation of crevasse traces. This is consistent with the changing flow regime of a glacier, since during a surge or rapid advance there is a switch from compressive flow at

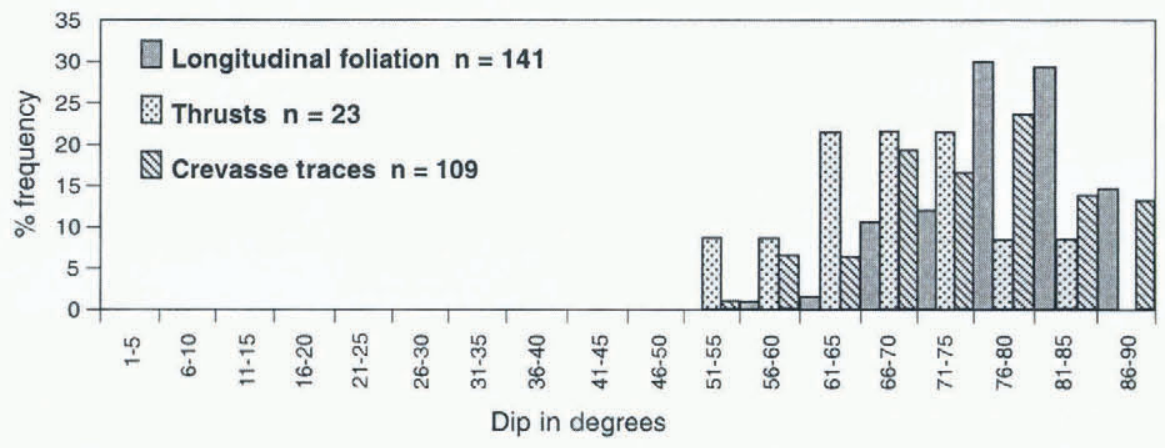

Fig. 5. Frequency histograms of the dip angles of longitudinal foliation, thrusts and crevasse traces recorded on the surface of Kongsvegen in fuly 1996. 

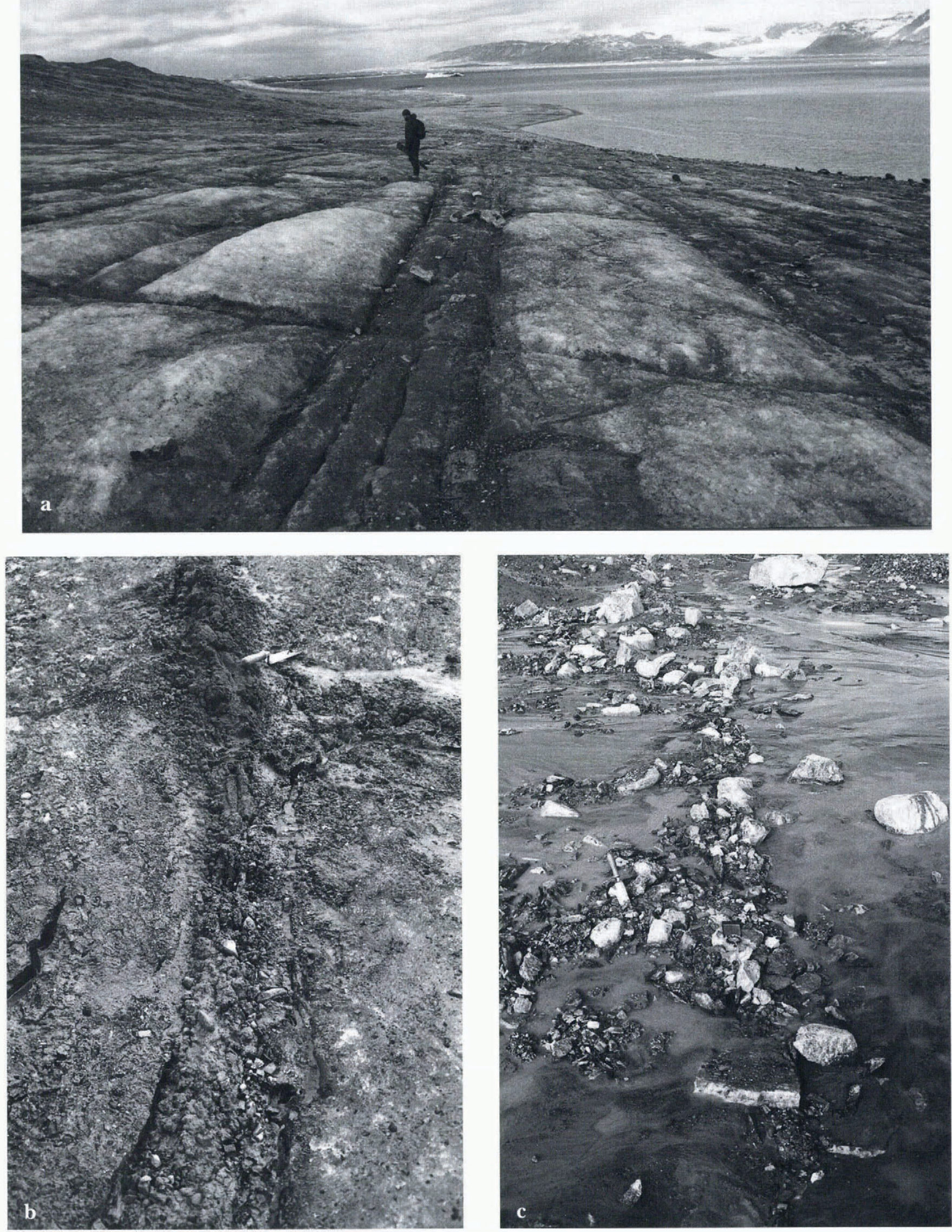

Fig. 6. Examples of longitudinal foliation and associated debris: (a) longitudinal foliation on the surface of Kongsvegen; note also the crevasse traces which cross the glacier surface perpendicular to the foliation; ( $b$ ) basal debris in longitudinal foliation on the surface of Kongsvegen; (c) a foliation-parallel ridge on the glacier forefield. Note the rounded clasts, many of which are striated and faceted, implying a basal origin. The area around the ridge is being infilled with mud and silt from active debris flows. 


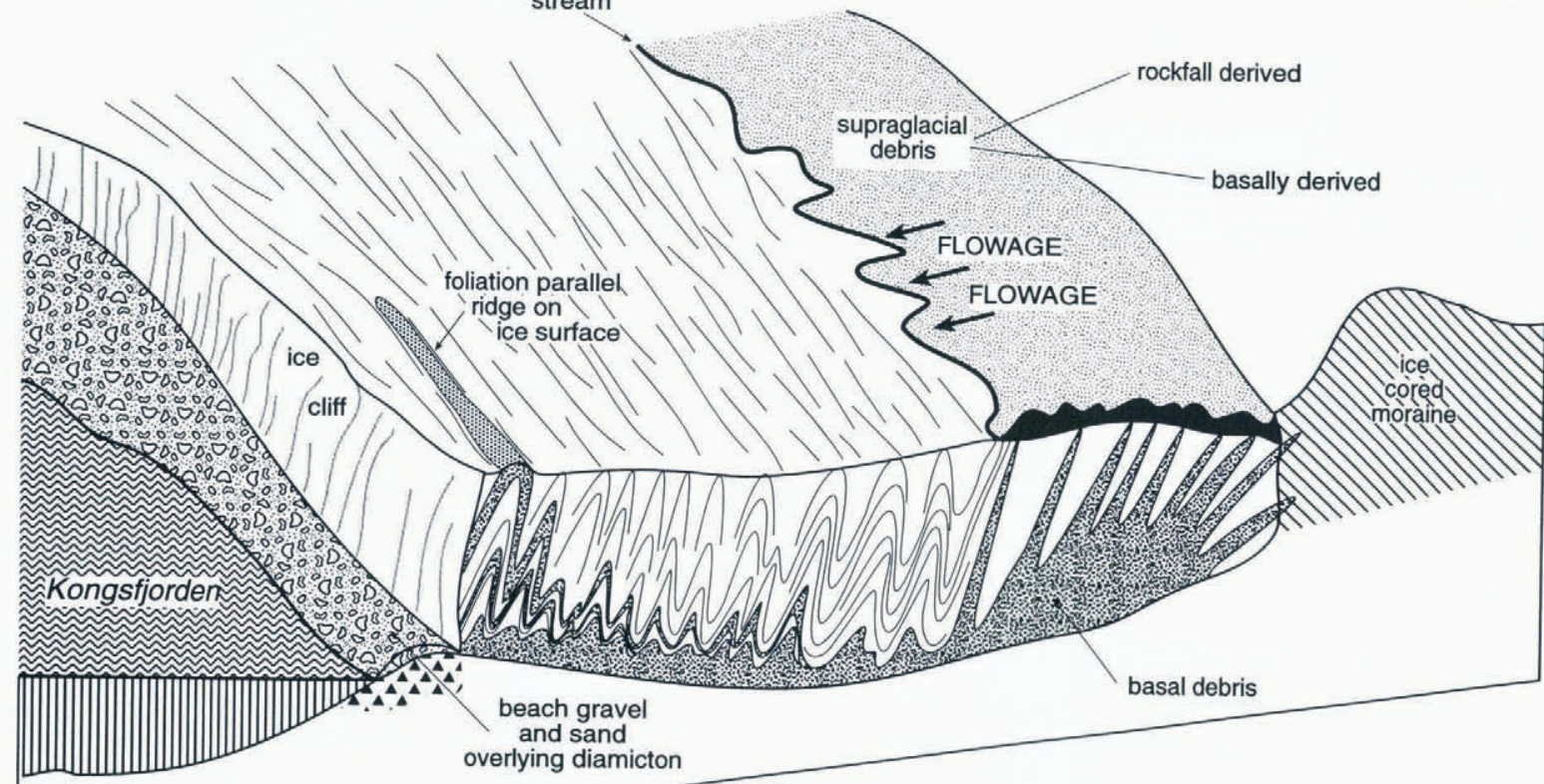

Fig. 7. Schematic cross-section of the terminal area of Kongsvegen, illustrating the inferred geometry of foliation and associated basal debris.

the surge front to extending flow as the surge front moves forward (Lawson and others, 1994). Field measurements on

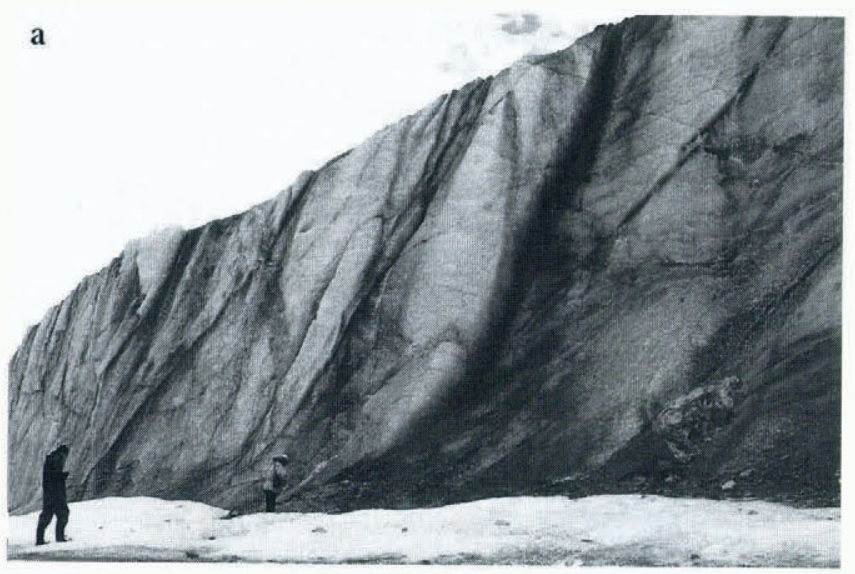

b

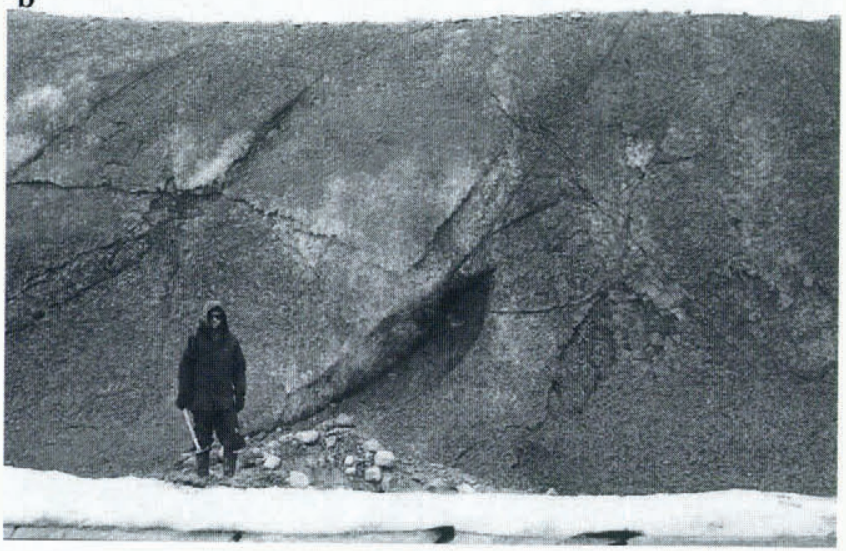

Fig. 8. Structures in the Kongsvegen ice cliff: (a) high-angle debris-rich thrusts rising from the glacier bed to penetrate the glacier surface; (b) a smaller debris-rich thrust. At its base, this thrust contains large amounts of basal debris, but it does not bring debris to the surface of the glacier. Note how the feature bifurcates in its upper parts into individual subsidiary thrusts.
Kongsvegen show that the crevasse traces have a remarkably consistent orientation, with an average strike of $175-355^{\circ}$ (Fig. 4). Dips vary between $50^{\circ}$ and $90^{\circ}$, with a modal class of $76-80^{\circ}$ (Fig. 5). The general orientation of crevasse traces is concave down-glacier. There is a broad zone of crevasse traces near the southern glacier margin, extending 400$500 \mathrm{~m}$ across the glacier surface. These are intersected by a second set of concave down-glacier crevasse traces.

\section{Debris-filled ice fractures in the base of the Kongs- vegen ice cliff $\left(\mathrm{S}_{4}\right)$}

A number of near-vertical fractures extend from the apparent base of the ice cliff upward for several metres. Their geometry is variable and some become inclined in an upglacier direction. These fractures are sometimes associated with basal debris. Their geometry suggests a different origin to the thrusts, and it is possible that these near-vertical fractures represent crevasse fillings of the type described by Sharp (1985).

\section{ICE-DEBRIS FACIES}

Debris-bearing glacier ice is found on the surface of Kongsvegen, in the Kongsvegen ice cliff, and in the landforms on the glacier forefield. Particle-shape data and laboratory particle-size analysis suggest that three main ice-debris facies are present: (1) sandy diamicton, (2) silty sand and (3) wellsorted sand (Fig. 9).

\section{(1) Sandy diamicton}

This facies occurs on the surface of Kongsvegen as (i) ridges of debris aligned transverse to glacier flow, and (ii) ridges of debris aligned parallel to longitudinal foliation. Sandy diamicton is also exposed in the Kongsvegen ice cliff, where pods of debris are found in association with thrusts rising from the base of the glacier. Finally, both longitudinal and transverse ridges composed of sandy diamicton are 
Thrust in ice cliff (sandy diamicton)

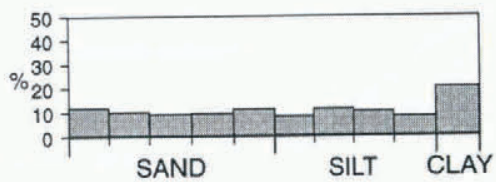

Thrust in ice cliff (sandy diamicton)

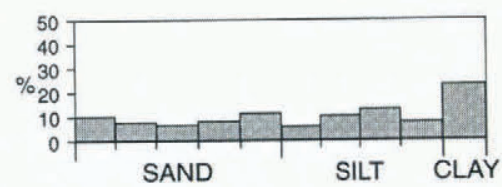

Thrust in ice cliff (sandy diamicton)

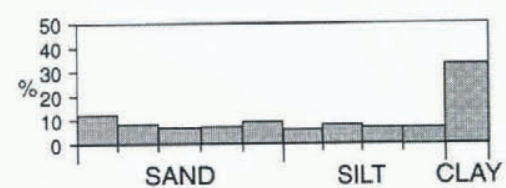

Thrust in ice cliff (sandy diamicton)

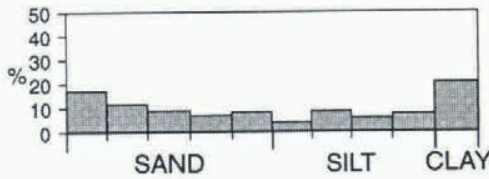

Thrust in ice cliff (sandy diamicton)

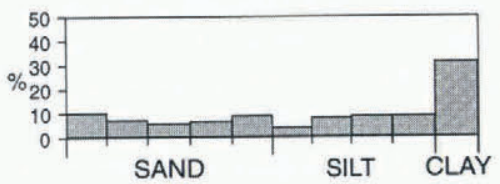

Transverse ridge on forefield (sandy diamicton)

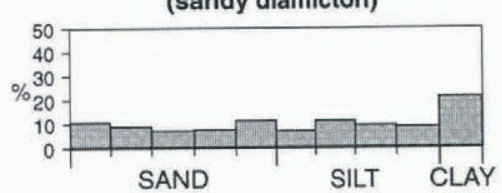

Transverse ridge on forefield (sandy diamicton)

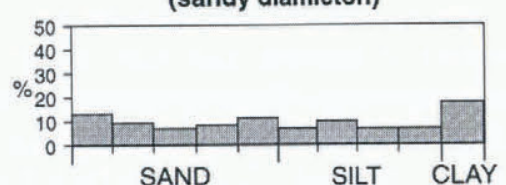

Foliation parallel ridge on glacier (sandy diamicton)

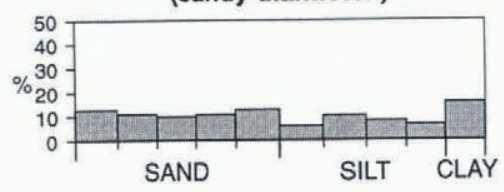

Foliation parallel ridge on glacier (sandy diamicton)

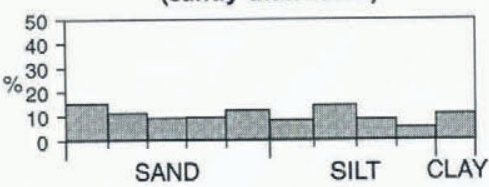

Foliation parallel ridge on glacier (sandy diamicton)

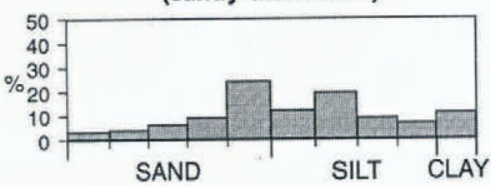

ongitudinal ridge on forefield (sandy diamicton)

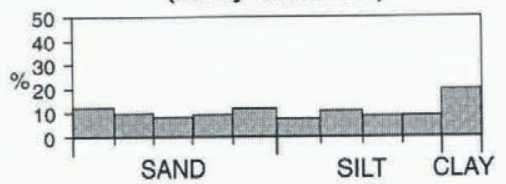

Supraglacial debris
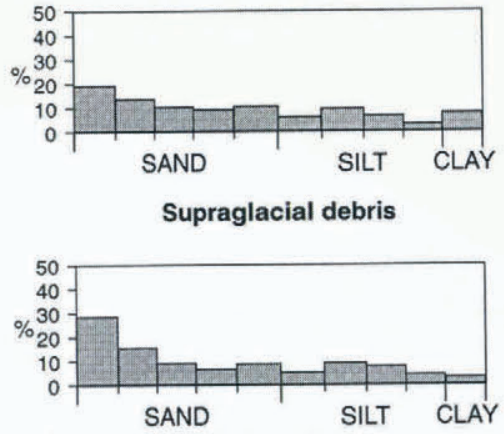

Dirt cone on glacier surface (englacial debris)

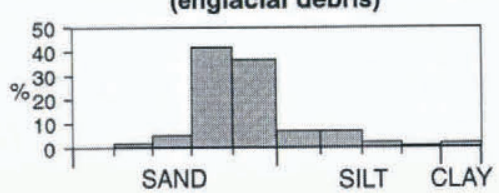

Fig. 9. Particle-size data from the matrix of thrusts in the Kongsvegen ice cliff, thrusts on the glacier surface, longitudinal foliation on the glacier surface, and both longitudinal and transverse ridges on the glacier forefield. For comparison, the matrices surrounding supraglacial debris on the glacier surface and of a dirt cone representing the path of a former englacial stream are shown.

observed on the glacier forefield immediately in front of the glacier terminus. The matrix is poorly sorted, with approximately equal proportions of sand, silt and clay. Clasts within this facies are predominantly rounded or subrounded, of mixed lithology and frequently striated and faceted (Fig. 10). This facies is interpreted as basally derived debris.

\section{(2) Silty sand}

This facies occurs in longitudinal ridges on Kongsvegen and as stripes of debris associated with medial moraines on the surface of the glacier. The matrix is moderately well sorted (Fig. 9). Clasts within this facies are almost exclusively angular (Fig. 10), are not striated and consist of locally derived schist. This facies is interpreted as the product of supraglacial rockfall onto the surface of the glacier.

\section{(3) Well-sorted sand}

This facies is represented by occasional mounds of debris and by dirt cones on the glacier surface. The matrix is well sorted, with a high proportion of sand (Fig. 9). Clasts within this facies are predominantly rounded, indicating a degree of fluvial action, and no striated clasts were observed. This facies is interpreted as a former stream deposit, in this case from a former englacial stream, which has risen to the surface along the longitudinal foliation in the manner described by Kirkbride and Spedding (1996). 


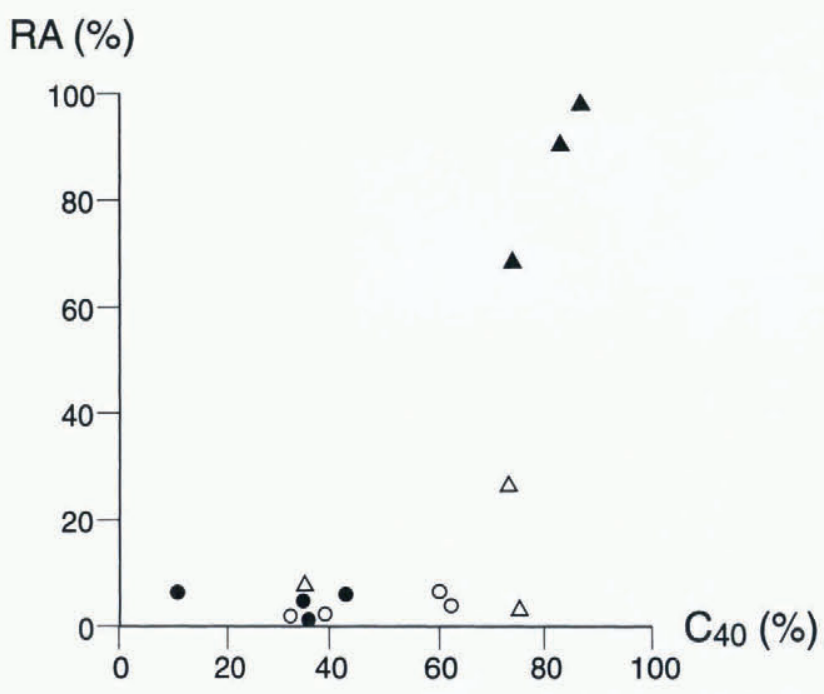

- thrusts on glacier surface

- thrusts in ice cliff

$\Delta$ foliation-parallel ridge composed of basal debris

- foliation-parallel ridge composed of supraglacial debris

Fig. 10. Clast-shape data from Kongsvegen shown as a covariant plot of the RA index (percentage of very angular and angular clasts within a sample) vs the C40 index (percentage of clasts with a c/a axial ratio of 0.4). Each symbol represents a sample of 50 clasts.

\section{LANDFORMS AND SEDIMENTS ASSOCIATED WITH THE 1948 ADVANGE OF KONGSVEGEN}

Longitudinal and transverse landforms with respect to Kongsfjorden are present in the proglacial area of Kongsvegen (Fig. 2). These landforms have been described as forming a geometrical ridge network (Bennett and others, 1996a). The transverse ridges are typically straight, sharpcrested and asymmetrical, with a well-defined morphology (Fig. 11). They are composed of a homogeneous sandy diamicton in which there is a predominance of subrounded particles. The presence of striated clasts suggests a basal origin for the material in these transverse ridges. In contrast, the longitudinal ridges are typically low and poorly defined, forming symmetrical ridges $10-60 \mathrm{~m}$ in length. They are texturally similar in composition to the transverse ridges, typically composed of sandy diamicton and gravel-rich sand. Clast shape is similar to that in the transverse ridges, but with a lower proportion of rounded and striated clasts. On this basis, a basal origin is also attributed to the debris in these ridges. The two types of ridges cannot be distinguished on the basis of clast lithology, since both contain a high proportion of locally derived clasts (Bennett and others, 1996a). Both transverse and longitudinal landforms can be observed melting out of the current ice margin. Post-depositional degradation of the ridges is common and there are two main processes that alter the morphology of individual ridges.

\section{Melting of an ice core}

Some ridges immediately in front of the glacier retain an ice core. Since mean summer temperatures in the area are commonly above freezing, thawing of this ice core results in widespread liquefaction of sediment. This characteristically leads to the slumping and subsequent reworking of the material in the ridges. Mass-movement and debris-flow processes aid this ridge collapse. Reworking of sediment in the ridges produces a more subdued morphology, as the area between individual ridges becomes infilled with mud and silt carried into the area by debris flows from higher on the valley side (Fig. 11).

\section{Ridge collapse due to desiccation}

Strong, dry winds are characteristic of the area, leading to desiccation of the surface of individual ridges. The surface sediment characteristically dries out into blocks and becomes friable, enabling large cracks to develop in the surface of the ridges. In many cases, this exposes the ice core beneath and enhances melt rates. Blocks of material are liable to topple and slide over the exposed ice beneath, providing material for the mass-movement processes outlined above. The effect of this is to reduce the size of individual features and to reduce their surface expression. The combination of ridge collapse and subsequent reworking means that the preservation potential of the low, longitudinal ridges is limited, although the larger transverse ridges are more likely to survive.

\section{DISCUSSION}

Studies of Svalbard glaciers suggest that there are four main methods of debris entrainment in polythermal glaciers (Hambrey and others, in press). These are the incorporation of debris in basal regelation ice; basal debris incorporated in association with thrusting; the folding of supraglacial and englacial material within ice; and the folding of material associated with englacial streams. The methuds of debris incorporation at Kongsvegen, its deformation in association with the development of ice structures, and subsequent release to produce landforms are summarised in Figure 12. The principal ice-structure/landform relationships are discussed below.

\section{Links between glacier structures and landforms}

The process of thrusting in glacier ice is now known to be an important process in moraine formation at high-Arctic glaciers, resulting in the formation of moraine-mound complexes (Hambrey and Huddart, 1995; Bennett and others, 1996a, b; Huddart and Hambrey, 1996; Hambrey and others, 1997). Data from the Kongsvegen ice cliff and from the glacier surface and forefield add to the credibility of this model of moraine formation. The basally derived sandy diamicton observed in cross-section in the thrusts of the Kongsvegen ice cliff can be traced to transverse ridges of sandy diamicton on the glacier surface. Furthermore, transverse ridges composed of the same material are commonly found melting out of the ice on the glacier forefield immediately in front of Kongsvegen (Fig. 13). Thus it is entirely possible for thrusts to bring basal debris to the glacier surface and for these ridges to be preserved during glacier recession. In the case of Kongsvegen these thrust ridges formed during a rapid advance, but this process occurs at the snouts of polythermal glaciers under both surge-type and "normal" flow conditions (Hambrey and others, 1997).

The foliation-parallel ridges on the surface of Kongsvegen and on the glacier forefield are also significant. Wherever these features are observed, they are orientated parallel 

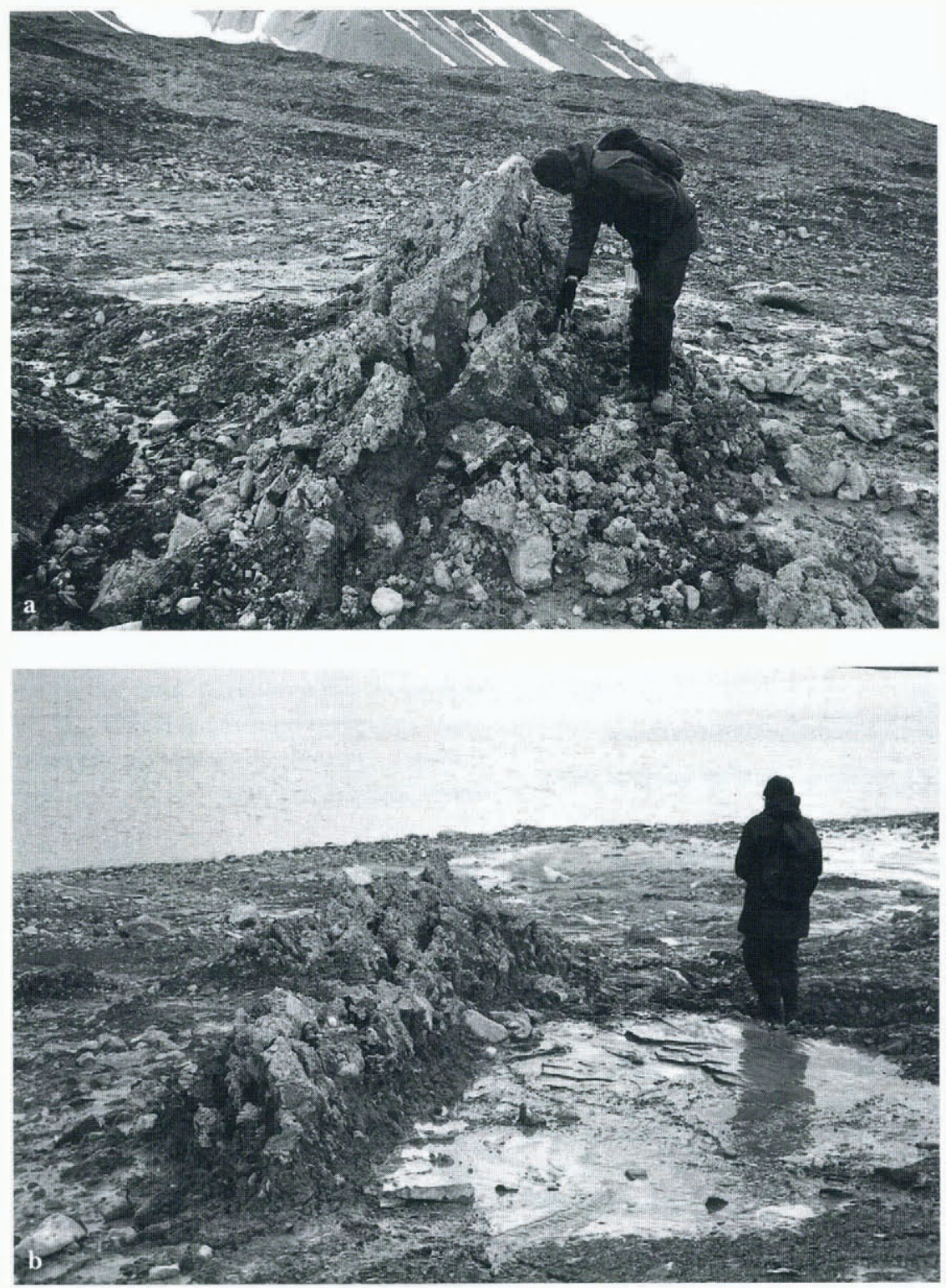

Fig. 11. Examples of typical transverse ridges on the glacier forefield: (a) straight, sharp-crested asymmetrical ridge; note the collapse of the down-glacier face and the compact up-glacier surface; $(b)$ ridge collapse due to desiccation and infill of intervening depression by sediment flow.

to the longitudinal foliation on Kongsvegen. Most of these longitudinal ridges are composed of the same basally derived sandy diamicton as the transverse ridges, although the foliation-parallel ridges on the glacier surface are occasionally composed of supraglacially derived sediment. The ridges of supraglacial material most commonly occur as medial moraines and are easily distinguished by their greater proportion of angular clasts. These ridges can be traced onto the glacier forefield as diffuse stripes of angular debris.

The incorporation of basal debris along longitudinal foliation is not a universally acknowledged process. The mechanism required to explain this process is one where lateral compression of ice leads to the development of a transposition foliation parallel to flow, combined with the incorporation of basal debris-rich ice or soft basal sediment in the fold complex. The resulting landforms at Kongsvegen are best described as "foliation-parallel ridges". There is therefore evidence for three debris entrainment processes operating at Kongsvegen. These are the incorporation of basal debris in association with (1) thrusting, (2) foliation development and (3) the folding of supraglacial debris to create englacial debris zones. Debris entrainment associated with regelation ice was not directly observed at Kongsvegen, because the base of the ice cliff is obscured by snow and cliff-fall material.

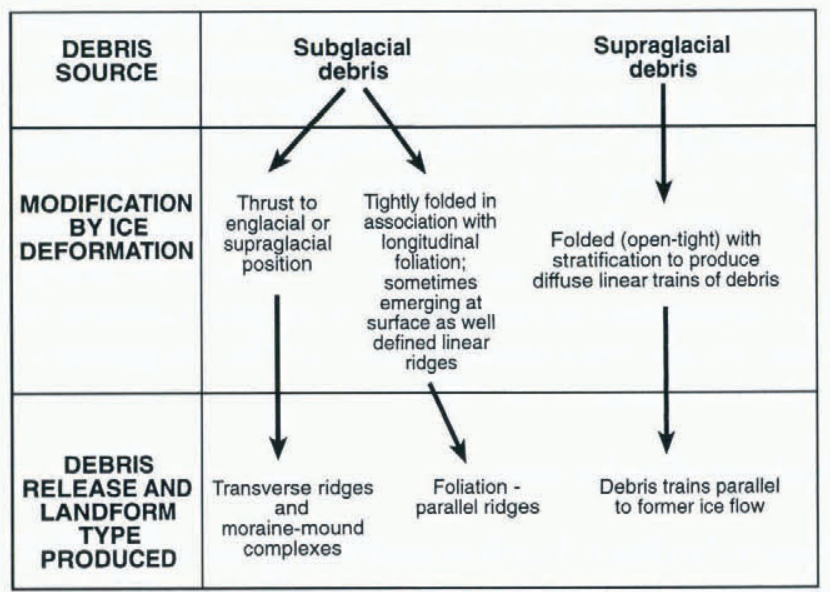

Fig. 12. Debris incorporation and deformation processes responsible for landform development at Kongsvegen. 


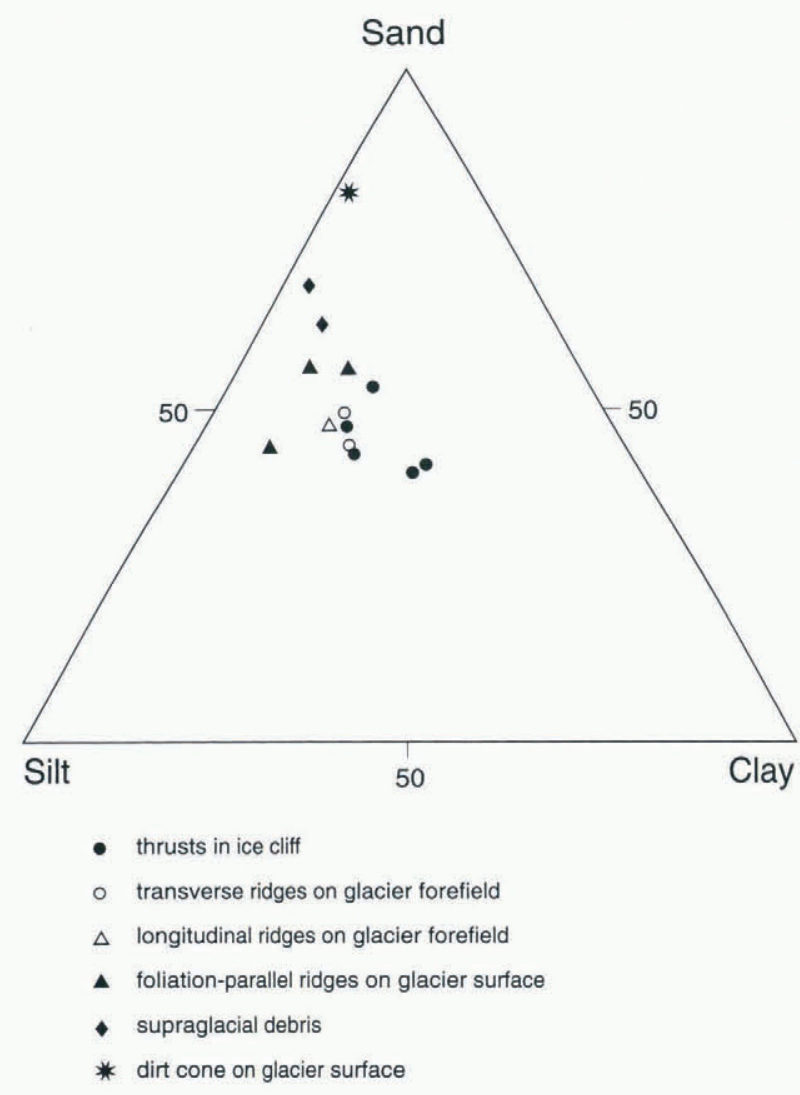

Fig. 13. Ternary diagram showing the proportions of sand, silt and clay in the matrix of the different facies identified at Kongsvegen. Note the similarity between the matrix of the thrusts in the ice cliff and the transverse ridges in front of the receding glacier, and between the foliation-parallel ridges on and off the glacier. Samples of supraglacial debris and a dirt cone are given for comparison.

\section{Comparisons between surge-type and non-surge- type glaciers}

The differences and similarities between the structures developed in surge-type and non-surge-type glaciers have been summarised by Hambrey and Dowdeswell (1997). Differences in structures are not as marked as might be expected, on the basis of approximately 12 glaciers investigated. Based on this small sample, it is not yet possible to discriminate between surge and non-surge landform assemblages. Thrusting is widespread in both types of glacier, and so thrust-moraines are ubiquitous in spite of statements to the contrary. The incorporation of debris parallel to foliation and subsequent generation of foliation-parallel ridges must be linked to a highly deformable bed. To date, basal debris associated with foliation has been found at both types of glacier, but only at Kongsvegen have the foliation-parallel ridges been observed. It is tentatively suggested that deformable bed conditions facilitate folding of basal debris with glacier ice to produce these ridges, but this hypothesis requires widespread testing.

\section{Implications for the interpretation of Pleistocene landforms}

The recognition of foliation-parallel ridges at modern glacier margins also has implications for the interpretation of Pleistocene landforms; in particular that of fluted terrain.
Two broad types of fluted terrain are commonly recognised (Heikkinen and Tikkanen, 1979; Rose 1987; Gordon and others, 1992): (1) flutes, low $(<3 \mathrm{~m})$, narrow $(<3 \mathrm{~m})$, regularly spaced ridges which are usually less than $100 \mathrm{~m}$ long and are common in front of modern glacier margins; and (2) megaflutes, which are much taller $(>5 \mathrm{~m})$, broader and longer $(>100 \mathrm{~m})$. Flutes have been widely interpreted as forming in the lee of subglacially lodged boulders (Dyson, 1952; Hoppe and Schytt, 1953; Schytt, 1963; Paul and Evans, 1974; Boulton, 1976), although several authors have challenged the ability of this mode of formation to explain all the observed forms (Karlén, 1981; Rose, 1989; Gordon and others, 1992). The formation of megaflutes is less well understood, and for the most part these features do not appear to be associated with cavities in the lee of boulders or bedrock obstacles. Several authors have suggested a genetic link between megaflutes and drumlinoid forms (Gravenor and Meneley, 1958; Prest, 1968; Aario, 1977; Rose, 1987; Clark, 1993).

The foliation-parallel ridges at Kongsvegen add to the range of mechanisms capable of producing low, linear ridges parallel to ice flow. It is therefore possible that some of the features previously interpreted as glacial flutes may in fact have their origin as foliation-parallel ridges. Foliation-parallel ridges formed from supraglacial sediment close to the ice surface should be identifiable on the basis of clast shape. They form distinct stripes of sediment, which resemble in morphology small glacial flutes. In contrast, foliation-parallel ridges composed of subglacial debris may be impossible to distinguish from conventional flutes since the fabric induced by folding into basal ice may be similar to that associated with sediment flow into a lee-side cavity. More observations are required concerning the range of size, length and morphology of foliation-parallel ridges. Until these data become available it is only possible to highlight the importance of this mechanism as a possible alternative when interpreting such landforms.

\section{CONCLUSIONS}

1. The main structures in Kongsvegen are: (i) stratification with a small amount of supraglacial debris that has been folded with flow-parallel axes; (ii) longitudinal foliation which in places incorporates basal glacial sediments by folding with flow-parallel axes; (iii) thrusts which are associated with basal debris and which sometimes carry basal debris to the surface; and (iv) crevasse traces which are not significant in terms of debris entrainment. Possible relict basal crevasses associated with subglacial debris are a minor feature observed at the foot of the ice cliff.

2. The principal landforms associated with these processes are transverse, asymmetrical ridges of thrust origin and foliation-parallel ridges.

3. The foliation-parallel ridges at Kongsvegen are low, linear ridges aligned parallel to ice flow. The process of debris entrainment along longitudinal foliation adds to the range of mechanisms capable of producing this type of landform. Recognition of foliation-parallel ridges in the Pleistocene record would have important implications for interpretation of the dynamics of former ice masses. 


\section{ACKNOWLEDGEMENTS}

This work was funded by a U.K. Natural Environment Research Council (NERC) grant (GR9/02185). We thank N. Cox at the NERC Arctic Research Station in Ny-Ålesund for logistical support. G. H. Sambrook Smith and two anonymous referees provided helpful comments on the manuscript.

\section{REFERENCES}

Aario, R. 1977. Associations of flutings, drumlins, hummocks and transverse ridges. Geofournal, 1, 65-72.

Allen, C. R., W. B. Kamb, M. F. Meier and R. P. Sharp. 1960. Structure of the lower Blue Glacier, Washington. f. Geol., 68(6), 601-625.

Benn, D. I. and C. K. Ballantyne. 1994. Reconstructing the transport history of glacigenic sediments: a new approach based on the co-variance of clast form indices. Sediment. Geol., 91 (1-4), 215-227.

Bennett, M. R., M. J. Hambrey, D. Huddart and J. F. Ghienne. 1996a. The formation of geometrical ridge networks ('crevasse-fill' ridges), Kongsvegen, Svalbard. 7. Quat. Sci., 11 (6), 430-438.

Bennett, M. R., D. Huddart, M. J. Hambrey and J. F. Ghienne. 1996b. Moraine development at the high-Arctic valley glacier Pedersenbreen, Svalbard. Geogr. Ann., 78A (4), 209-222.

Björnsson, H. and 6 others. 1996. The thermal regime of sub-polar glaciers mapped by multi-frequency radio-echo sounding. 7. Glaciol., 42(140), 23-32.

Boulton, G. S. 1976. The origin of glacially fluted surfaces - observations and theory. F. Glaciol., 17 76), 287-309.

Casassa, G. 1992. Foliation on Tyndall Glacier, southern Patagonia. Bull. Glacier Res. 10, 75-77.

Clark, C. D. 1993. Mega-scale glacial lineations and cross-cutting ice-flow landforms. Earth Surface Processes and Landforms, 18 (1), 1-29.

Dyson, J. L. 1952. Ice-ridged moraines and their relation to glaciers. Am. J. Sci., 250 (3), 204-211.

Elverhøi, A., O. Liestøl and J. Nagy. 1980. Glacial erosion, sedimentation and microfauna in the inner part of Kongsfjorden, Spitsbergen. Nor. Polarinst. Skr. 172, 33-61.

Gordon, J. E., W. B. Whalley, A. F. Gellatly and D. M. Vere. 1992. The formation of glacial flutes: assessment of models with evidence from Lyngsdalen, north Norway. Quat. Sci. Rev., 11 (7-8), 709-731.

Gravenor, C. P. and W. A. Meneley. 1958. Glacial flutings in central and northern Alberta. Am. J. Sci., 256 (10), 715-728.

Hagen, J. O. and A. Sxtrang. 1991. Radio-echo soundings of sub-polar glaciers with low-frequency radar. Polar Res., 9 (1), 99-107.

Hagen, J. O., O. Liestøl, E. Roland and T. Jørgensen. 1993. Glacier atlas of Svalbard and Jan Mayen. Nor. Polarinst. Medd. 129.

Hambrey, M. J. 1975. The origin of foliation in glaciers: evidence from some Norwegian examples. f. Glaciol., 14(70), 181-185.

Hambrey, M. J. 1977. Foliation, minor folds and strain in glacier ice. Tectonophysics, 39 (1-3), 397-416.

Hambrey, M. J. and J. A. Dowdeswell. 1997. Structural evolution of a surgetype polythermal glacier: Hessbreen, Svalbard. Ann. Glaciol., 24, 375-381.

Hambrey, M. J. and D. Huddart. 1995. Englacial and proglacial glaciotectonic processes at the snout of a thermally complex glacier in Svalbard. 7. Quat. Sci., 10 (4), 313-326.

Hambrey, M.J. and A. G. Milnes. 1975. Boudinage in glacier ice-some examples. J. Glaciol., 14(72), 383-393.
Hambrey, M.J. and F. Müller. 1978. Structures and ice deformation in the White Glacier, Axel Heiberg Island, Northwest Territories, Canada. J. Glaciol., $20(82), 41-66$.

Hambrey, M.J., J. A. Dowdeswell, T. Murray and P. R. Porter. 1996. Thrusting and debris entrainment in a surging glacier: Bakaninbreen, Svalbard. Ann. Glaciol., 22, 241-248.

Hambrey, M. J., D. Huddart, M. R. Bennett and N. F. Glasser. 1997. Genesis of 'hummocky moraines' by thrusting in glacier ice: evidence from Svalbard and Britain. 7. Geol. Soc., London, 153 (4), 623-632.

Hambrey, M.J., M. R. Bennett, J. A. Dowdeswell, N. F. Glasser and D. Huddart. In press. Debris-entrainment in polythermal valley glaciers. 7. Glaciol.

Heikkinen, O. and M. Tikkanen. 1979. Glacial flutings in northern Finnish Lapland. Fennia, 157 (1), 1-12.

Hisdal, V. 1976. Geography of Svalbard. Oslo, Norsk Polarinstitutt. (Polarhåndbok 2.)

Hooke, R. LeB. and P.J. Hudleston. 1978. Origin of foliation in glaciers. $\mathcal{F}$. Glaciol., 20(83), 285-299.

Hoppe, G. and V. Schytt. 1953. Some observations on fluted moraine surfaces. Geogr. Ann., 35(2), 105-115.

Huddart, D. and M.J. Hambrey. 1996. Sedimentary and tectonic development of a high-Arctic, thrust-moraine complex: Comfortlessbreen, Svalbard. Boreas, 25 (4), 227-243.

Hudleston, P. J. and R. LeB. Hooke. 1980. Cumulative deformation in the Barnes Ice Cap and implications for the development of foliation. Tectonophysics, 66(1-3), 127-146.

Karlén, W. 1981. Flutes on bare bedrock. J. Glaciol., 27(95), 190-192.

Kirkbride, M. and N. Spedding. 1996. The influence of englacial drainage on sediment-transport pathways and till texture of temperate valley glaciers. Ann. Glaciol., 22, 160-166.

Lawson, W. J., M. J. Sharp and M. J. Hambrey. 1994. The structural geology of a surge-type glacier. J. Struct. Geol., 16(10), 1447-1462.

Lefauconnier, B., J. O. Hagen and J. P. Rudant. 1994. Flow speed and calving rate of Kongsbreen glacier, Svalbard, using SPOT images. Polar Res., $13(1), 59-65$.

Liestøl, O. 1977. Setevatnet, a glacier dammed lake in Spitsbergen. Nor. Polarinst. Arbok 1975, 31-35.

Liestøl, O. 1988. The glaciers in the Kongsfjorden area, Spitsbergen. Nor. Geogr. Tidsskr., 42(4), 231-238.

Melvold, K. 1992. Studie av brebevegelse på Kongsvegen og Kronebreen, Svalbard. Oslo, Universitetet i Oslo. (Rapportserie i Naturgeografi 1.)

Paul, M. A. and H. Evans. 1974. Observations on the internal structure and origin of some flutes in glacio-fluvial sediments, Blomstrandbreen, north-west Spitsbergen. 7. Glaciol., 13 (69), 393-400.

Powers, M. C. 1953. A new roundness scale for sedimentary particles. 7 . Sediment. Petrol., $23(2), 117-119$.

Prest, V. K. 1968. Nomenclature of moraines and ice-flow features as applied to the glacial map of Canada. Geol. Surv. Can. Pap. 67-57.

Ragan, D. M. 1969. Structures at the base of an ice fall. 7. Geol., 77 (6), 647-667.

Raymond, C. F. 1987. How do glaciers surge? A review. 7. Geophys. Res., 92(B9), 9121-9134.

Rose, J. 1987. Drumlins as part of a glacier bedform continuum. In Menzies, J. and J. Rose, eds. Drumlin Symposium. Rotterdam, A.A. Balkema, 103-116.

Rose, J. 1989. Glacier stress patterns and sediment transfer associated with the formation of superimposed flutes. Sediment. Geol., 62 (3-4), 151-176.

Schytt, V. 1963. Correspondence. Fluted moraine surfaces. F. Glaciol., 4(36), 825-827.

Sharp, M. 1985. "Crevasse-fill" ridges - a landform type characteristic of surging glaciers? Geogr. Ann., 67A(3-4), 213-220. 